\title{
IMPACT OF CHLORIDES, NITRATES, SULFATES AND PHOSPHATES ON INCREASED LIMESTONE DISSOLUTION IN THE KARST VADOSE ZONE (POSTOJNA CAVE, SLOVENIA)
}

\author{
VPLIV KLORIDOV, NITRATOV, SULFATOV IN FOSFATOV NA \\ POVEČANO RAZTAPLJANJE APNENCA V VADOZNI CONI \\ KRASA (POSTOJNSKA JAMA, SLOVENIJA)
}

Janja KOGOVŠEK ${ }^{1}$

\begin{abstract}
UDC 551.444:504.5(497.471)

551.311.2:552.541(497.471)

Janja Kogovšek: Impact of chlorides, nitrates, sulfates and phosphates on increased limestone dissolution in the karst vadose zone (Postojna Cave, Slovenia)

Distinctive karst hydrology arises from a combination of high carbonate rock solubility and well developed secondary porosity (fissures). Soil $\mathrm{CO}_{2}$ is the most important influence on solubility of carbonate rock (Ford \& Williams 2007). Human activity on the karst surface results in pollution that has an important influence on water quality. Degradation of organic pollution (e.g. waste water, leachates from landfill sites) results in inorganic acids too. These acids could have an important additional influence on dissolution of carbonate rocks in the vadose zone. In the framework of more than 20 years of research on precipitation percolation and transfer of contaminants (direct outflow of waste water from a small military facility where about twenty troops were stationed) through the 100-m thick vadose zone of Postojna Cave, contaminated water was observed in drips and trickles in the cave (up to $60 \mathrm{mg} \mathrm{Cl}^{-} / 1$, up to $180 \mathrm{mg} \mathrm{NO}_{3}^{-} / \mathrm{l}$, up to $2.8 \mathrm{mg} \mathrm{PO}_{4}^{3-} / 1$, and up to $50 \mathrm{mg} \mathrm{SO}_{4}^{2-} / \mathrm{l}$ ). At the same time the sum of calcium and magnesium $(\mathrm{Ca}+\mathrm{Mg})$ of trickles was up to two times larger than the $\mathrm{Ca}+\mathrm{Mg}$ of either the uncontaminated reference trickle or the input waste water. The amount of dissolved limestone carried by waste water to trickles and drips in the cave was directly proportional to the concentration of contaminant anions present. This demonstrates that there is an accelerated widening of fissures below source points of wastewater. Water with contaminants can penetrate faster and deeper into the vadose zone along the increasingly permeable fissures without losing its dissolving power, and thus significant dissolution occurs ever deeper in the vadose zone. This results in ever faster penetration of contaminants through the vadose zone. In the final phase of such development, which takes many decades or longer, relatively rapid transfer of contaminants through the aquifer all the way to karst springs with minimal self-cleansing effects can be expected.
\end{abstract}

Keywords: karst, vadose zone, pollution, increased dissolution, accelerated karstification.

Izvleček

UDK 551.444:504.5(497.471)

551.311.2:552.541(497.471)

Janja Kogovšek: Vpliv kloridov, nitratov, sulfatov in fosfatov na povečano raztapljanje apnenca $v$ vadozni coni krasa (Postojnska jama, Slovenija)

Kraški vodonosniki so pomemben vir pitne vode, vendar so zelo ranljivi. Dobra topnost karbonatnih kamnin in njihova sekundarna poroznost sta pogojevali razvoj značilne kraške hidrologije. Za raztapljanje karbonatnih kamnin je najodgovornejši $\mathrm{CO}_{2}$ v prsti (Ford \& Williams 2007), vendar pa v procesu raztapljanja lahko sodelujejo tudi anorganske kisline, ki so rezultat razgradnje organskega onesnaženja. V okviru več kot 20-letnega raziskovanja pretakanja padavin in prenosa kontaminantov (neposredni iztok komunalne odpadne vode iz vojaškega objekta s približno dvajsetimi vojaki) skozi $100 \mathrm{~m}$ debelo vadozno cono Postojnske jame smo ugotavljali onesnaženo preniklo vodo več curkov in kapljanj v jami (z do $60 \mathrm{mg} \mathrm{Cl}^{-} / \mathrm{l}$, do $180 \mathrm{mg} \mathrm{NO}_{3}^{-} / 1$, do $2,8 \mathrm{mg} \mathrm{PO}_{4}^{3-} / 1$, do $\left.50 \mathrm{mg} \mathrm{SO}_{4}^{2-} / 1\right)$. Hkrati je bila $v$ teh curkih vsota kalcija in magnezija do dvakrat večja kot v čistem referenčnem curku oz. v odpadni vodi. Količina raztopljenih karbonatov je bila premo-sorazmerna količini prisotnih kontaminantov. To je nakazovalo na povečano širjenje prevodnikov neposredno pod virom onesnaženja. Zato se $\mathrm{s}$ časom kontaminanti prenašajo vse hitreje globlje $\mathrm{v}$ vadozno cono, tako da prihaja do pomembnega raztapljanja kamnine vse globlje. V končni fazi razvoja, ki traja več desetletij in več, lahko pričakujemo hiter prenos kontaminantov skozi vodonosnik vse do kraških izvirov $\mathrm{z}$ minimalnimi učinki samoočiščevanja.

Ključne besede: kras, vadozna cona, onesnaženje, povečano raztapljanje, pospešeno zakrasevanje.

${ }^{1}$ Karst Research Institute ZRC SAZU, Titov trg 2, 6230 Postojna, Slovenia, e-mail: kogovsek@zrc-sazu.si

Received/Prejeto: 23.12.2011 


\section{INTRODUCTION}

Karst areas are found on about 15 percent of the earth's surface, and twenty to twenty-five percent of the world's population drinks water from karst aquifers (Ford \& Williams 2007). This percentage is expected to rise substantially in the future (Forti 2002). Karst aquifers hold significant amounts of groundwater, and since carbonate rock covers 35\% of the surface in Europe (COST Action 65, 1995), and in Slovenia some $44 \%$ of the surface (Gams 2003), they are an important source of drinking water. In addition to their quantity, the quality of karst waters is becoming increasingly important. In order to preserve the existing quality of karst water resources, it is necessary to reduce the emission of dangerous substances on the surface and at the same time study their impact on water quality and on permeability of the vadose zone in the aquifer.

On the karst surface the most important quantitative biotic contribution to karstification is the production of $\mathrm{CO}_{2}$ in soil (Ford \& Williams 2007). Human activities on the karst surface produce different types of pollution (e.g. waste waters, landfill sites, agriculture, traffic) that influence karst water quality (Kogovšek 1987, 1994, 1995, 1997, 2004; Bolner et al. 1989; Guo et al. 2010). Evidence from the literature indicates serious pollution problems are particularly evident in the quickly developing countries (Jiang et al. 2009; Shi et al. 2009; Zhang et al. 2008, and many others).
Degradation of organic pollution (such as waste waters and leachates from municipal landfill sites) results in inorganic acids too. These acids can have an important influence on increased dissolution of carbonate rocks. More than 20 years of research on water percolation and transfer of contaminants from a pollution source on the surface through the 100-m thick karst vadose zone in a research area of Postojna Cave have enabled study of the impact of increased content of the contaminants nitrates, chlorides, sulfates and $o$-phosphates on the process of limestone dissolution. My hypothesis was that higher concentration of ions of inorganic acids causes greater dissolution of limestone. Increased dissolution means an accelerated widening of fissures in the vadose zone, which allows in time more rapid transfer of contaminants and poorer processes of self-cleansing on the way through the vadose zone of the aquifer to karst springs.

Continuous measurements of precipitation on the surface and the discharge, electrical conductivity (EC), temperature measurements and chemical analyses of selected trickles in the study area in Postojna Cave that began in 2003 and are still in progress, and tracer tests with fluorescence tracers through the vadose zone as well as use of isotopic analyses of ${ }^{18} \mathrm{O}$ are helping us to understand the hydrodynamics and the closely connected transfer of contaminants (Kogovšek 2010).

\section{RESEARCH AREA}

In the early 1980s, speleologists drew our attention to pollution visible on stalactites in Postojna Cave. Sampling of trickles over a wider area in the caves indicated that the percolated water was polluted at a number of points (trickles I, J, L, G and H). The source of pollution was a small military facility, where about twenty troops were stationed, on the surface above this part of Postojna Cave (Fig. 1).

The area immediately above the study area in Postojna Cave is covered with grass and a thin layer of soil (about $10 \mathrm{~cm}$ ), and the surroundings are overgrown with forest. The main source of pollution in the trickles in Postojna Cave, $100 \mathrm{~m}$ below the surface, was waste water that after sedimentation in the sedimentation pool drained first into a cesspool about four meters deep and then percolated in the direction of observed trickles in the cave. In the spring of 1991 the military facility was closed and fresh pollution stopped. Precipitation con- tinued to wash the remaining pollution from the cesspool and from the cave's roof. In the period from 1991 to 2006 , the average annual precipitation was $1500 \mathrm{~mm}$.

I focused my detailed monitoring (discharge, temperature and EC) on three of the most contaminated trickles (I, J and L) with diversely permeable catchment areas that flow through tectonically fissured and broken zones and along bedding planes (Kogovšek \& Šebela 2004). For comparison an uncontaminated trickle, A, was monitored. The maximum discharges of trickles varied from a few $\mathrm{ml} / \mathrm{min}$ to a hundred or several thousand $\mathrm{ml} / \mathrm{min}$. The discharge of the largest periodic trickle I can reach up to 4 liters per minute and reacts the most rapidly of all the trickles to sufficiently abundant precipitation. In wet periods it responds to precipitation events with a rapidly increasing discharge that reaches its maximum value in 6 to 60 hours, and in the absence of precipitation it dries up quickly. The less abundant trickle J, 


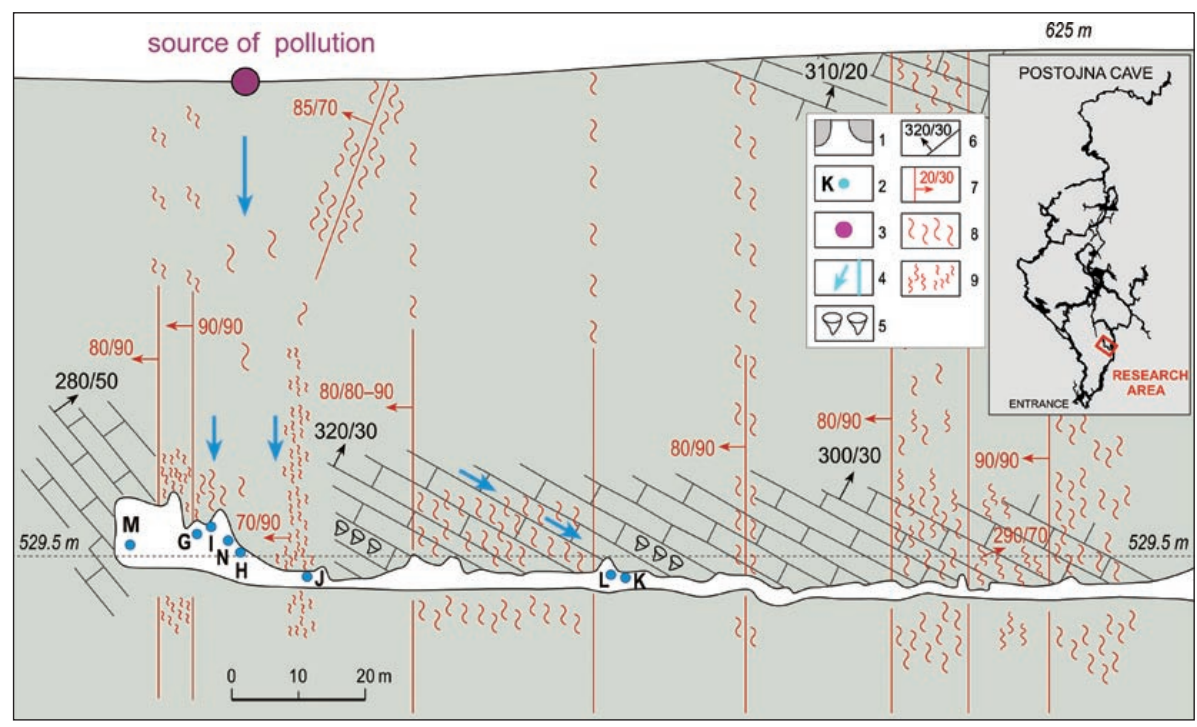

Fig. 1: The source of pollution in the trickles in Postojna Cave ( $I$, $J, L, G$ and H) $100 m$ below the surface, was wastewater outflow on the surface.1. Cross section of cave, 2. Observed trickle, 3. Source of pollution, 4. Direction of percolated water, 5.Upper Cretaceous limestone with remains of rudists, 6. Strike and dip of bedding planes, 7. Strike and dip of fault, 8. Fissured zone, 9. Broken zone.

whose annual outflow is more than 20 times lower than that of trickle I, exhibits a strong damping of infiltrated precipitation. Throughout the year this trickle never runs dry, and it reacts to precipitation with a large time delay (up to two days) compared to trickle I. Its flood waves are characterized by slowly increasing and decreasing discharges that achieve maximum values up to $130 \mathrm{ml} /$ min. With maximum discharge of only a few $\mathrm{ml} / \mathrm{min}$, the permanent trickle $\mathrm{L}$ has a completely different and unique discharge pattern (Kogovšek 2010).

\section{METHODOLOGY}

The first periodic samplings, measurements and analyses of several contaminated trickles with varying discharges in Postojna Cave (contaminated trickles I, J, L, G, H) and the pure uncontaminated trickle A began in 1988 . Samples were collected manually in polyethylene bottles by simply waiting for the bottles to fill up. During periods of very low discharge the bottles were set up and the samples were collected the next morning. I tried to capture the characteristics of the chemical composition of the water under various hydrological conditions such as low and high discharges and increasing and decreasing flow rates. Later, in 2002, frequent systematic sampling of trickles was done. In the fall of 2003, automatic samplers were installed at trickles I and J that took samples one to six times daily, most frequently during flood waves following precipitation events. Parallel continuous measurements of discharge, temperature and EC were made. EC and tracer tests showed the different lengths of time infiltrated precipitation with contaminants is retained in the variously permeable parts of the vadose zone. The results of these tests were supported by isotopic analyses of oxygen that showed that the average retention time of water is around 2.5 months in the more permeable parts of the vadose zone (trickle I) and substantially longer, more than a year, in the less permeable parts (trickle J) (Kogovšek 2010).

In the laboratory water samples were analyzed immediately for carbonate, calcium, magnesium, chloride, nitrate, sulfate, and $o$-phosphate content. We determined the content of chlorides using the standard method with mercury nitrate, of sulfates using the standard turbidimetric method, of $o$-phosphates using the standard method with tin chloride, of carbonates, calcium, and magnesium using the titrimetric methods (Standard Methods 1992), and of nitrate using a method employing sodium salicylate. 


\section{RESULTS}

During our research it was not possible to sample waste water from the military facility above the research area in Postojna Cave. However, analysis of similar waste water outflow from sanitary facilities and washrooms of the nearby campground at Pivka jama (Kogovšek 1987) showed high values of organic pollution (chemical oxygen demand up to $600 \mathrm{mgO}_{2} / \mathrm{l}$ ), high concentrations of chlorides (up to $50 \mathrm{mg} \mathrm{Cl}^{-} / \mathrm{l}$ ), phosphates (up to $14 \mathrm{mg}$ $\mathrm{PO}_{4}^{3-} / \mathrm{l}$ ) and ammonia at relatively low concentration of nitrates. The well ventilated vadose zone enabled efficient oxidation of ammonia to nitrates. The sum of calcium and magnesium $(\mathrm{Ca}+\mathrm{Mg})$ was $210 \mathrm{mg} \mathrm{CaCO}_{3} / \mathrm{l}$. Later analysis of waste water outflow from a house showed similar values of contaminants, and the value of $\mathrm{Ca}+\mathrm{Mg}$ was $150 \mathrm{mg} \mathrm{CaCO} / 1$, close to the value of drinking water in this region, which varies during the year between 170 and $220 \mathrm{mg} \mathrm{CaCO}_{3} / \mathrm{l}$.
In the monitored period between 1988 and 1992, trickles I and $\mathrm{J}$ in Postojna Cave displayed the highest content of chlorides (up to $60 \mathrm{mg} \mathrm{Cl} / \mathrm{l}$ ), nitrates (up to $180 \mathrm{mg} \mathrm{NO}_{3}^{-} / \mathrm{l}$ ), $o$-phosphates (up to $2.8 \mathrm{mg} \mathrm{PO}_{4}^{3-} / \mathrm{l}$ ), and sulfates (up to $50 \mathrm{mg} \mathrm{SO}_{4}^{2-} / \mathrm{l}$ ), increased values of EC (up to $1150 \mu \mathrm{S} / \mathrm{cm}$ ), and an increased content of calcium and $\mathrm{Ca}+\mathrm{Mg}$ relative to the unpolluted reference trickle $\mathrm{A}$ (up to $3 \mathrm{mg} \mathrm{Cl}^{-} / \mathrm{l}$, up to $5 \mathrm{mg} \mathrm{NO}_{3}^{-} / \mathrm{l}$, up to $0.1 \mathrm{mg} \mathrm{PO}_{4}^{3-} / 1$ and up to $8 \mathrm{mg} \mathrm{SO}_{4}^{2-} / \mathrm{l}$ ) (Fig. 2). Ca+Mg of trickles I and J was up to two-fold higher than that of the uncontaminated reference trickle $\mathrm{A}$ or than the value of $\mathrm{Ca}+\mathrm{Mg}$ reached by trickles I and J from 1997 onward, when the concentrations of contaminants increased only minimally (with the exception of $o$-phosphates) or than the value of $\mathrm{Ca}+\mathrm{Mg}$ of input waste water. After the military barracks were closed and active pollution ceased in 1991, the following three years saw a rapid decline in the concentration of all contaminants in trickles $\mathrm{I}, \mathrm{J}$, and $\mathrm{L}$ due to natural leaching by precipitation. Over $4,700 \mathrm{~mm}$ of precipitation fell during this period. A portion of the contaminants was retained in only the less permeable part of the catchment area. In the following years, a slower decline in the concentration and values approaching the values of the uncontaminated reference trickle A were recorded (Kogovšek 2010).

Analyses of $\mathrm{Ca}+\mathrm{Mg}$ of trickles I and J showed values up to around $500 \mathrm{mg}$ $\mathrm{CaCO}_{3} / 1$, while values for the uncontaminated trickle A were around $225 \mathrm{mg} \mathrm{CaCO}_{3} / 1$.

Fig. 2: The transfer of contaminants (chlorides and nitrates) through trickles I and $J$ was reflected in greater electric conductivity (EC) and greater concentrations of calcium and magnesium $(\mathrm{Ca}+\mathrm{Mg})$ in period from 1988 to 1996. For comparison measurements of uncontaminated trickle $A$ are presented. 


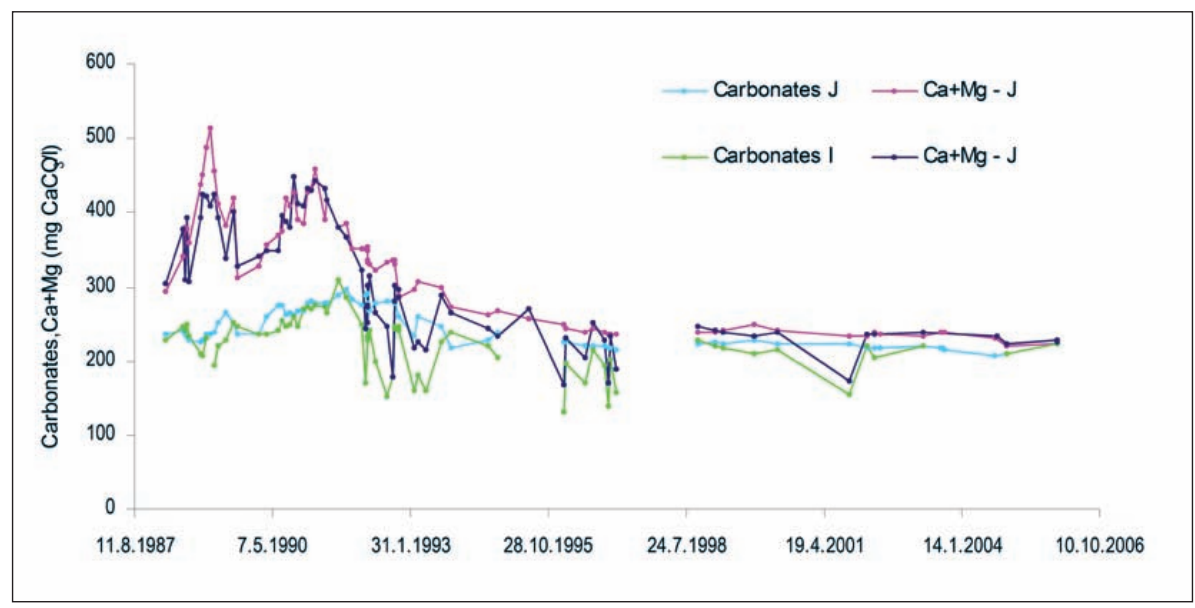

Fig. 3: The pattern of carbonate content and sum of calcium and magnesium $(\mathrm{Ca}+\mathrm{Mg})$ in trickles I and J during an 18-year period.

of contaminants present (the sum of chlorides, nitrates, $o$-phosphates, and sulfates). Fig. 5 shows the measurements for trickles I and J, which display a di-

The pattern of carbonate content and $\mathrm{Ca}+\mathrm{Mg}$ in trickle I and trickle J (Fig. 3) was approximately the same. Occasional low values of carbonate content and $\mathrm{Ca}+\mathrm{Mg}$ in trickle I stand out during minimal discharge periods, due to deposition of calcium carbonate during the slow flow along the flowstone formation prior to sampling. More frequent sampling of trickle I over the course of several flood waves when the discharge was increasing showed a simultaneous drop in both parameters. Abundant precipitation results in a significant contribution of new, less mineralized water in this trickle (Kogovšek 2010). In trickle J a high degree of homogenization without larger oscillations is evident. The transfer of contaminants, EC and discharge pattern and isotopic analysis of ${ }^{18} \mathrm{O}$ (Kogovšek 2010) reflect the structure of the catchment area of the trickles and indicate a high level of homogenization in the catchment area of trickle J, due to its hierarchy of variously less permeable and hydraulically connected fissures, in comparison with that of trickle I.

A comparison of $\mathrm{EC}$ and $\mathrm{Ca}+\mathrm{Mg}$ indicated linear dependency in both trickles (Fig. 4). For trickle I we excluded samples taken at minimal discharges, when significant deposition of calcium carbonate occurs and the samples therefore do not reflect the composition of water flowing at the top of the flowstone formation. The correlation coefficient of $\mathrm{Ca}+\mathrm{Mg}$ and $\mathrm{EC}$ was $\mathrm{R}^{2}=0.97$ for trickle $\mathrm{I}$, and $\mathrm{R}^{2}=0.99$ for trickle J. It follows that in this case EC is a good measure of the amount of limestone dissolved in the percolated water.

That foreign ions in karst waters affect the ionic strength has been established both in theory and by laboratory experiments (Dreybrodt 1988, 2000). An increase in ionic strength decreases the solubility product, and calcite solubility increases (Dreybrodt 2000). In the Postojna Cave study area, these effects were measured in a natural environment. The amount of dissolved limestone carried by water to trickles in the cave or its $\mathrm{Ca}+\mathrm{Mg}$ was directly proportional to the amount rectly proportional relationship $\left(\mathrm{R}^{2}=0.78\right.$ for trickle I and $\mathrm{R}^{2}=0.84$ for trickle J). However, some other anions that are also present but were not included in the analyses probably affect the dissolution of limestone. These anions are represented by the difference between $\mathrm{Ca}+\mathrm{Mg}$ and carbonates $((\mathrm{Ca}+\mathrm{Mg})$-carbonates). $\mathrm{Ca}+\mathrm{Mg}$ is directly proportional to the amount of these anions ( $\mathrm{R}^{2}=0.9$ for both trickles).

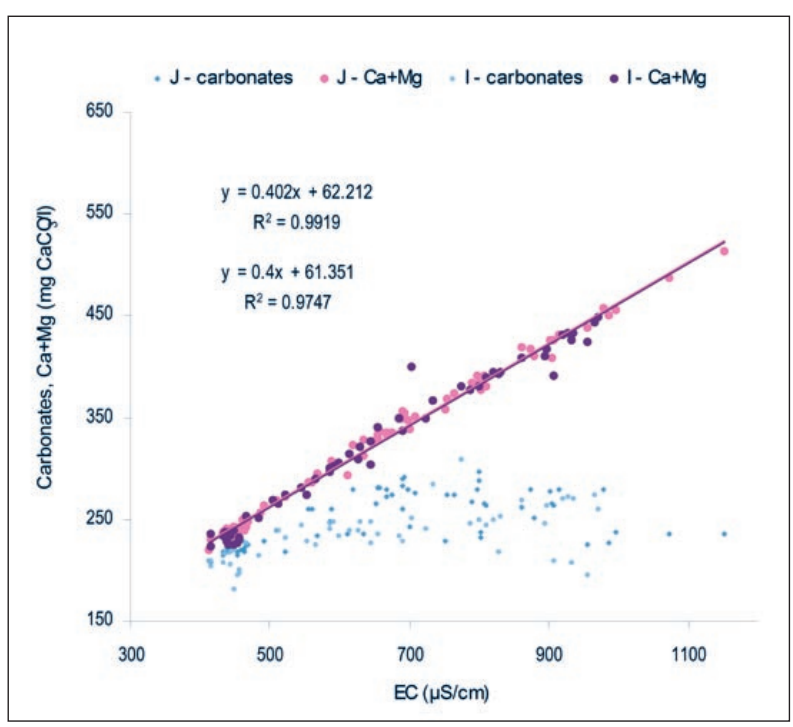

Fig. 4: Dependence between EC and concentration of $(\mathrm{Ca}+\mathrm{Mg})$ and carbonates in trickles I and J.

From these results it follows that the important dissolution of limestone in the vadose zone was due to the presence of contaminants, particularly the anions of strong acids originating from pollution (direct outflow of waste water) on the surface. This process of dissolution depends very heavily on the hydrodynamics of waste water, which can be retained in the vadose zone for various time periods that may be extended by months during dry periods. 


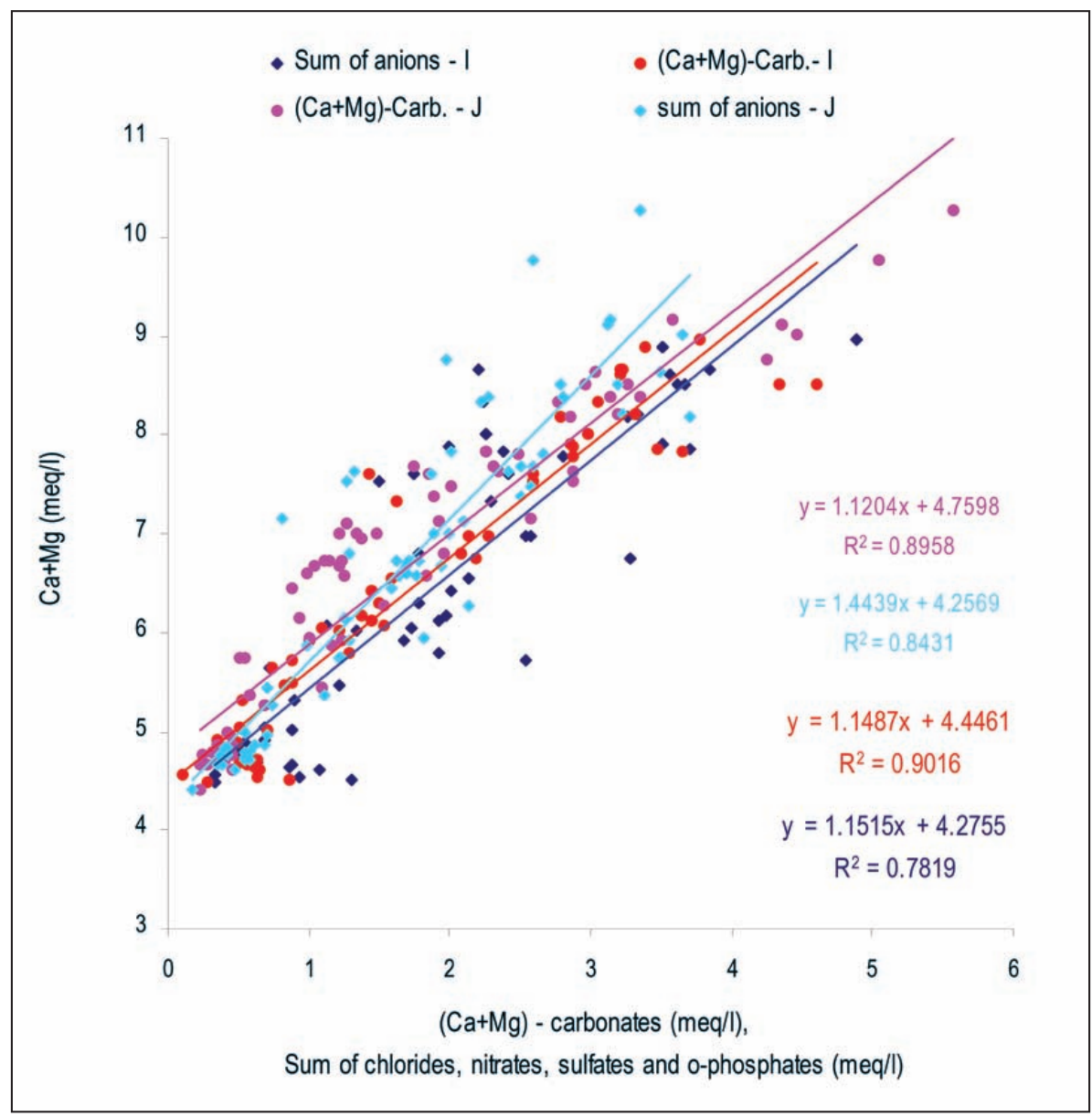

Fig. 5: Trickles I and J - in addition to the amount of $\mathrm{CO}_{2}$ in the water, the dissolution of carbonate rock in the vadose zone depends on the amount of chlorides, nitrates, sulfates, and ophosphates (sum of "anions") or other anions present represented by the difference between the sum of calcium and magnesium and carbonates ((Ca+Mg)-Carb.). For better comparison the concentrations of all ions are expressed in meq/l.

sium and carbonate concentrations during the long observation period, but in the case of carbonates in trickle A the oscillations do not exceed $20 \mathrm{mg} \mathrm{CaCO} / 1$.

It is obvious that chlorides, nitrates, sulfates, and phosphates play an important role in the dissolution of limestone in the vadose zone above Postojna Cave because like the anions of strong acids they replace

Following the highest values of $\mathrm{Ca}+\mathrm{Mg}$ recorded prior to 1992 (a year after the military facility was closed), when trickles I and J reached values up to twice the value of the uncontaminated reference trickle A or around $200 \mathrm{mg} \mathrm{CaCO} / 1$ higher values, the content of carbonates in trickles I and J only reached at most values $60 \mathrm{mg} \mathrm{CaCO} / 1$ higher than the reference trickle $\mathrm{A}$ (Fig. 6). Of course, all trickles experience seasonal and discharge-dependent oscillations in calcium, magne- carbonate ions in the limestone during the dissolution process and release $\mathrm{CO}_{2}$. That this released $\mathrm{CO}_{2}$ or the resulting carbonic acid $\left(\mathrm{H}_{2} \mathrm{CO}_{3}\right)$ is capable of additional corrosion is reflected in the slightly increased carbonates during the period of high values of these contaminants (Fig. 6). When the $\mathrm{Ca}+\mathrm{Mg}$ of trickles J and I dropped to $250 \mathrm{mg} \mathrm{CaCO}_{3} / \mathrm{l}$ at the end of 1996 , less than $4 \mathrm{mg} \mathrm{Cl}^{-} / \mathrm{l}$ of chlorides, less than $20 \mathrm{mg} \mathrm{SO}{ }_{4}^{2-} / 1$ of sulfates, and less than $20 \mathrm{mg} \mathrm{NO}_{3}^{-} / 1$ of nitrates were present; $o$-phosphates,

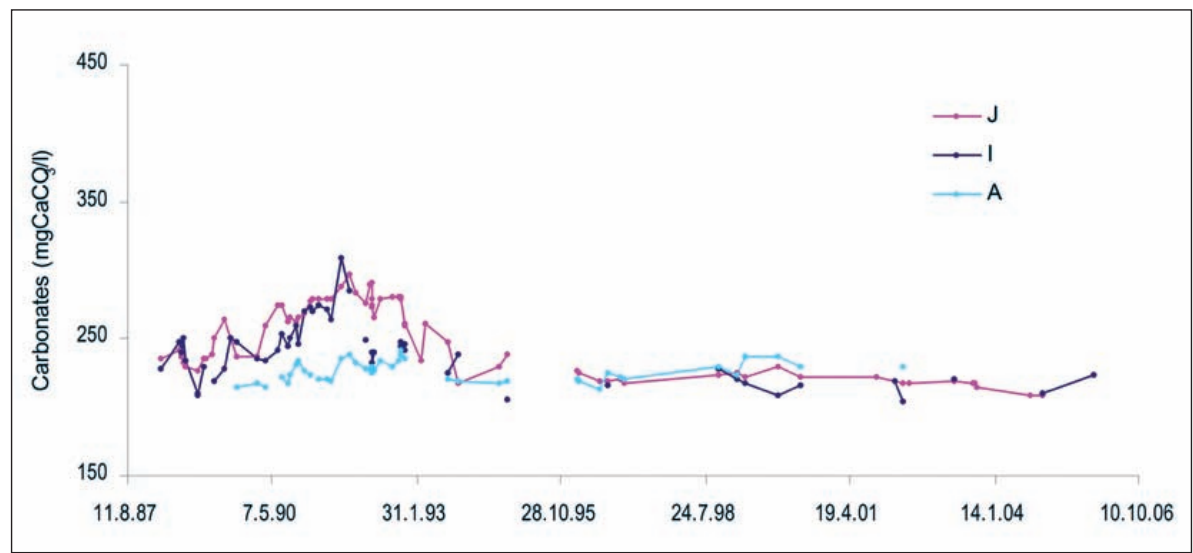

Fig. 6: Content of carbonates of trickles I and J and of uncontaminated reference trickle $A$. 
however, remained increased and reached values just below $0.4 \mathrm{mg} \mathrm{PO}_{4}^{3-} / \mathrm{l}$ in trickle I and $1.4 \mathrm{mg} \mathrm{PO}_{4}^{3-} / 1$ in trickle $\mathrm{J}$. Limestone dissolution due to the presence of contaminants was minimal, and additional dissolution attributable to the presence of contaminants was undetectable by the methods applied.

From the results it follows that in the case of the smaller release of previously sedimented wastewater above Postojna Cave directly into the vadose zone, the dissolution of limestone in the 100-m thick cave roof in the period from 1988 to 1992 was up to two times greater than in trickles in the immediate vicinity but outside the area of pollution. This demonstrates that there is an accelerated widening of fissures below source points of wastewater (chlorides, nitrates, sulfates and phosphates). Water with contaminants can penetrate faster and deeper into the vadose zone along the increasingly permeable fissures without losing its dissolving power, and thus significant dissolution occurs ever deeper in the vadose zone. In the final phase of the development of increasingly permeable fissures, a very rapid transfer of contaminants through the vadose zone and further through the aquifer along channels to karst springs with minimal self-cleansing effects can be expected.

\section{DISCUSSION}

The simultaneous increased values of $\mathrm{Ca}+\mathrm{Mg}$ and contaminants (chlorides, nitrates, sulfates, and $o$-phosphates) in the monitored trickles in Postojna Cave showed a linear dependency between the two categories, which means that these contaminants cause the increased dissolving of limestone. In the area where wastewater was discharged (up to $60 \mathrm{mg} \mathrm{Cl}^{-} / 1$, up to $180 \mathrm{mg} \mathrm{NO}_{3}^{-} / 1$, up to $2.8 \mathrm{mg} \mathrm{PO}_{4}^{3-} / \mathrm{l}$, and up to $50 \mathrm{mg} \mathrm{SO}_{4}^{2-} / \mathrm{l}$ ), the dissolving rate was up to twice as fast as in other areas in the immediate vicinity but outside the pollution area. This results in the accelerated widening of fissures in the vadose zone, which allows the ever more rapid transfer of contaminants through the vadose zone. In the final phase of such development, which takes many decades or longer, the relatively rapid transfer of contaminants through the aquifer all the way to karst springs can be expected.

The increased dissolution of limestone and the subsequent gradual enlargement of permeable fissures allow the increasingly rapid transfer not only of soluble contaminants but also of insoluble contaminants such as oil derivatives. When these fissures become large enough, they can even allow the transfer of solid organic particles, as observed in trickle I in Postojna Cave (Kogovšek 1997) and in Pivka jama (Kogovšek 1987).

In Germany, a study on the impact of old waste dump sites on springs showed increased mineralization and an increased content of chlorides, nitrates, and sulfates in the springs (Hötzl 1995). In the framework of tracer tests at municipal landfill sites in the karst regions of Slovenia (injections on the karst surface), measurements of precipitation and the discharge of springs showed that during dry periods periodic precipitation infiltrated the layers of waste and partly into the vadose zone, but there was frequently no immediate discharge from the vadose zone. Infiltrated precipitation can be stored in landfills and the vadose zone for weeks or months, and nitrates, phosphates, chlorides and sulfates can react with carbonate material that is used to cover garbage already in the landfill (Kogovšek 1996). However, more abundant and intense precipitation pushed the stored water containing contaminants deeper into the vadose zone below, where increased dissolution of carbonate rock can occur.

The tracer tests from Sežana and Kočevje landfill sites showed a significant transfer of injected tracer in the first wave of tracer at the springs: $40 \%$ from Sežana landfill to Timavo spring (Kogovšek \& Petrič 2007), $80 \%$ from Kočevje landfill to Bilpa spring within half a month (Kogovšek \& Petrič 2010) and probably a similar percentage from the Ribnica landfill (Kogovšek \& Petrič 2006) (an estimate was made for the Ribnica landfill since there is no data on the discharge of the springs). These results indicated very permeable vadose zone below landfill sites, that are 34-41 years in operation. In contrast, the tracer test from Poček military training area, where the pollution is dispersed more widely on the karst surface, showed that only $4 \%$ of the injected tracer flowed through the Malenščica spring in the first wave of tracer. When using the same manner of injection as in the case of tracer tests from landfill sites, a considerably larger amount of precipitation (above $100 \mathrm{~mm}$ ) was required to start the transfer of tracer from Poček (Kogovšek 1999). 


\section{CONCLUSIONS}

Based on the above-mentioned results in Postojna Cave, we can conclude that localized wastewater sources on karst terrain that discharge directly into the karst environment, and probably other similar sources such as leachate waters from landfills, foster the intense dissolution of limestone in the vadose zone. This leads to the gradual formation of local increasingly permeable fissures that drain precipitation containing leached contaminants from landfill sites ever more rapidly through the vadose zone to underground watercourses and on to karst springs. This explains the rapid percolation of tracer through the vadose zones below the mentioned municipal landfill sites (Kogovšek \& Petrič 2004, 2006, 2007,2010 ) even in dry periods.

The hydrological conditions have an important influence on transport of contaminants and their dissolution effects on carbonate rocks in the vadose zone and consequently on the quality of springs.
It is therefore necessary to anticipate the local increased dissolution of limestone and consequently the greater permeability of fissures and conduits in karst vadose zones for water and contaminants below wastewater sources with high concentrations of chlorides, nitrates, sulfates and phosphates. In the final phase of such development, which takes many decades or even longer, the relatively rapid transfer of contaminants through the aquifer all the way to karst springs can be expected. The increased permeability of fissures and conduits allows the rapid transfer not only of soluble potentially dangerous substances but also of insoluble contaminants such as oil derivatives. More detailed measurements must be done in the future to define these processes more precisely.

\section{ACKNOWLEDGEMENT}

The research was supported by the Slovenian Research Agency, Karst Research Program and Slovene National Commission for UNESCO, IHP Program.

\section{REFERENCES}

Bolner, T., Tardy, J. \& L. Nemedi, 1989: Evaluation of the Environmental Impacts in Budapest's caves on the Basis of the Study of the Quality of Dripping Waters.- Proceedings of $10^{\text {th }}$ International Congress of Speleology, $13^{\text {th }}-20^{\text {th }}$ August, Budapest, 2, 634-639.

COST Action 65, 1995: Hydrogeological aspects of groundwater protection in karstic areas. Final report. European Commission, Directorate-General XII, Science, Research and Development, Report EUR $16574 \mathrm{EN}$.

Dreybrodt, W., 1988: Processes in Karst Systems (Physics, Chemistry, and Geology).- Springer Verlag, pp. 288, Berlin.

Dreybrodt, W., 2000: Equilibrium Chemistry of Karst Water in Limestone Teranes.- In: Klimchouk, B., Ford, C.D., Palmer, A.N. \& W. Dreybrodt (eds.) Speleogenesis. National Speleological Society, pp. 126-135, Huntsville.
Ford, D. \& P. Williams, 2007: Karst Hydrogeology and Geomorphology.- John Wiley \& Sons: pp. 562, Chichester.

Forti, P., 2002: Speleology in the Third Millennium: Achievements and Challenges.- Theoretical and Applied Karstology, 15, 7-26.

Gams, I., 2003: Kras v Sloveniji v prostoru in času.Založba ZRC, ZRC SAZU, pp. 516, Ljubljana.

Guo, F., Yuan, D. \& Z. Qin, 2010: Groundwater contamination in karst areas of southwestern China and recommended countermeasures.- Acta carsologica, 39, 2, 389-399.

Hötzl, H., 1995: Project II - Bauschotter limestone platform.- In: Hydrogeological aspects of groundwater protection in karstic areas. COST action 65. Final report, 124-131, Brussels-Luxembourg. 
Jiang,Y., Wu, Y., Groves, C., Yuan, D. \& P. Kambesis, 2009: Natural and anthropogenic factors affecting the groundwater quality in the Nandong karst underground river system in Yunnan, China.- Journal of Contaminant Hydrology, 109, 49-61.

Kogovšek, J., 1987: Naravno čiščenje sanitarnih odplak pri vertikalnem prenikanju v Pivki jami $=$ Natural purifications of sanitary sewage during the vertical percolation in Pivka jama.- Acta carsologica, 16, 121-139.

Kogovšek, J., 1994: Impact of human activity on Škocjanske jame.- Acta carsologica, 23, 73-80.

Kogovšek, J., 1995: Some examples of the karst water pollution on the Slovene karst.- Acta carsologica, 26, 303-312.

Kogovšek, J., 1996: Kako smetišča ogrožajo kakovost kraške vode $=$ How rubbish dumps have imperilled the quality of karst water.- Annales, 9, 111-114.

Kogovšek, J., 1997: Pollution transport in the vadose zone.- In: Günay G., Johnson A. I., Tezcan L \& A.Ö. Atilla (eds.) Karst waters \& environmental impacts, Proceeding of $5^{\text {th }}$ international symposium and field seminar on karst waters and environmental impacts, $10^{\text {th }}-20^{\text {th }}$ September 1995, Antalya, Turkey. A.A. Balkema, 161-165, Rotterdam.

Kogovšek, J., 1999: Nova spoznanja o podzemnem pretakanju vode $\mathrm{v}$ severnem delu Javornikov (Visoki kras) = New knowledge about the underground water drainage in the Northern part of Javorniki Mountains (High Karst).- Acta carsologica, 28, 1, 161-200.

Kogovšek, J., 2004: Fizikalno-kemične značilnosti voda v zaledju Malenščice (Slovenija) = Physico-chemical properties of waters in the Malenščica recharge area (Slovenia).- Acta carsologica, 33, 1, 143-158.
Kogovšek, J., 2010: Characteristics of percolation through the karst vadose zone.- Carsologica. Založba ZRC SAZU, pp.168, Postojna-Ljubljana.

Kogovšek, J. \& M. Petrič, 2004: Advantages of longerterm tracing -- three case studies from Slovenia.Environmental geology, 47, 1, 76-83.

Kogovšek, J. \& M. Petrič, 2006: Tracer test on the Mala gora landfill near Ribnica in south-eastern Slovenia = Sledilni poskus na odlagališču Mala gora pri Ribnici v jugovzhodni Sloveniji.- Acta carsologica, 35, 2, 91-101.

Kogovšek, J. \& M. Petrič, 2007: Directions and dynamics of flow and transport of contaminants from the landfill near Sežana (SW Slovenia) $=$ Smeri in dinamika odtekanja vode in prenosa kontaminantov Z odlagališča odpadkov pri Sežani (JZ Slovenija).Acta carsologica, 36, 3, 413-424.

Kogovšek, J. \& M. Petrič, 2010: Tracer tests as a tool for planning the monitoring of negative impacts of the Mozelj landfill (SE Slovenija) on the karst. Acta carsologica, 39, 2, 301-311.

Kogovšek, J. \& S. Šebela, 2004: Water tracing through the vadose zone above Postojnska Jama, Slovenia.- Environmental Geology, 45, 992-1001.

Shi, Z., Liu, X., Liu, Y., Huang, Y. \& H. Peng, 2009: Catastrophic groundwater pollution in a karst environment: a study of phosphorus sludge waste liquid pollution at the Penshuidong Cave in Yunnan, China.- Environ Earth Sci, 59, 757-763.

Standard Methods for Examination of Water and Wastewater, 1992, $18^{\text {th }}$ Edition, Washington.

Zhang, G., Zhou, C. \& X. Kang, 2008: Changing features of water quality in the Nandong underground river, Kaiyuan, Yunnan.- Carsologica sinica, 27, 4, 366370. 